\title{
FEMORAL FRACTURE HOSPITALIZATIONS AMONG THE ELDERLY IN RORAIMA, BRAZIL
}

\section{COMMUNICATION}

BORGHETTI, Gina ${ }^{1}$

BORGHETTI, Gina. Femoral fracture hospitalizations among the elderly in Roraima, Brazil. Revista Científica Multidisciplinar Núcleo do Conhecimento. Year. 07, Ed. 01, Vol. 02, pp. 111-119. January 2022. ISSN: 2448-0959, Access Link: https://www.nucleodoconhecimento.com.br/health/femoral-fracture, DOI: 10.32749/nucleodoconhecimento.com.br/health/femoral-fracture

\section{ABSTRACT}

Introduction: Femoral fractures in the elderly increase the risk of morbidity and mortality, and are usually necessary for hospitalization. Due to the relevance of the theme in public health and the lack of information about the situation in the state in the period between 2015 and 2019, the following question arose: According to age group and gender, what is the profile of hospital admissions due to femoral fracture among the elderly in Roraima in this period? Objective: To describe hospital admissions for femoral fracture among the elderly, between 2015 and 2019 in the State of Roraima, Brazil. Method: This is a descriptive study, with a quantitative approach, using data from the Hospital Information System[2] of the Unified Health System[3] in the period from 2015 to 2019. For frequency analyses, codes related to femoral fracture were used according to the 10th revision of the International Classification of Diseases, age group, gender and hospital deaths. Results: It was observed that female gender was the most prevalent in hospitalizations for femur fracture (56.4\%). Stratified by age group, 80 years and more represented $38.7 \%$ of hospitalizations, mostly women. This same profile was observed when hospitalizations for femoral fracture with proximal location were analyzed. Among

\footnotetext{
${ }^{1} \mathrm{PhD}$ in Cellular and Molecular Biology, Master in Cell and Molecular Biology, Degree in Physiotherapy. ORCID: https://orcid.org/0000-0002-2922-9090.
} 
hospitalizations with the outcome of death due to femoral fracture, there was a predominance among women aged 80 years and over (66.7\%). Final considerations: In this study, it was observed that hospitalizations and hospital deaths due to femoral fracture were more prevalent in octogenarian women. Health strategies, such as the prevention of falls, should be directed to the elderly population, especially women, who are the most affected by this disease.

Keywords: Femoral Fractures, Hospitalization, Elderly, Public Health.

\section{INTRODUCTION}

The demographic transition occurs in Brazil simultaneously with the growing and progressive aging of the population, affecting health services and the socioeconomic conditions of society (TRAVASSO et al., 2020). Factors related to aging in association with frailty, osteoporosis and the presence of comorbidities increase the occurrence of fractures among the elderly (PETERLE et al., 2019; WU et al., 2019). A study conducted in Brazil in 2013 showed a prevalence of three simultaneous diseases in the population aged 60 years or older. Other factors such as loss of muscle function and poor physical performance are also indicative of unfavorable events in this population (PETERLE et al., 2019).

Most femoral fractures in the elderly are secondary to accidental falls, and surgical treatment is the most widely used procedure (BORTOLON et al., 2011; ARMOND et al., 2014). In Brazil, the prevalence of at least one drop in 2019 ranged from $25.1 \%$ to $37.07 \%$ (SANTOS et al., 2021). However, this event should not be seen as part of natural aging (PORTO et al., 2019). Falls could be prevented with interventions through guided physical exercises, early identification of risk factors and the treatment of osteoporosis, especially in postmenopausal women (BEER and GILES, 2005).

Research indicates that the increase in femoral fractures is related to the advancement of age and gender (BORTOLON et al., 2011). These fractures can occur in different anatomical areas of the femur, such as the proximal region, the 
diaphysis and the distal region (EDELMUTH et al., 2018). Studies indicate that fractures located in the proximal femur, mainly due to osteoporosis, exhibit a higher risk of morbidity and mortality and recurrent fractures (CHEN et al., 2018; CARMO and GOMES, 2008).

Femoral fractures increase the risk of mortality among the elderly, especially if associated with factors such as age group, comorbidities, gender and the presence of cognitive impairment (PETERLE et al., 2019; NETO et al., 2011). It was demonstrated that one year after surgical treatment, about $50 \%$ of the elderly presented difficulties in daily activities and ambulation (MACEDO et al., 2019). They usually have reduced autonomy and loss of quality of life (MACEDO et al., 2019; NASCIMENTO, 2019). Additionally, they can cause psychosocial impacts and generate additional financial costs for the health and family system, as these elderly generally require longer hospitalization and rehabilitation (SANTOS et al., 2021; OLIVEIRA and BORBA, 2017).

Femoral fractures in the elderly increase the risk of morbidity and mortality and are usually necessary for hospitalization. Information on hospital admissions can help in the knowledge of this health situation and in prevention strategies for this population. Due to the relevance of the theme in public health and the lack of information about the situation in the state in the period between 2015 and 2019, the following question arose: According to age group and gender, what is the profile of hospital admissions due to femoral fracture among the elderly in Roraima in this period?

In view of the context presented, this study aims to describe hospital admissions for femoral fracture among the elderly, between 2015 and 2019 in the State of Roraima, Brazil.

\section{METHOD}

This is a descriptive study with a quantitative approach. The database was collected from the Hospital Information System of the Unified Health System (SIH/SUS), which originates from the Authorizations for Hospital Admissions[4] (AlH'S) of the 
Department of Informatics of the SUS (DATASUS). The database was selected by the Federation Unit (Roraima) and year/month of processing (period between January 2015 to December 2019). To describe hospital admissions due to femoral fracture, the following variables were selected: Chapters of the International Classification of Diseases (ICD-10), Deaths (with death, without death), Age group (60 to 69 years, 70 to 79 years and 80 years and over) and Gender (female, male). The AlH'S recorded in the SIH/SUS database as Femoral Fracture were analyzed, according to the 10th revision of the International Classification of Diseases (ICD-10) contained in Chapter XIX, Injuries, poisoning and other consequences of external causes. In one analysis, all codes related to femur fracture (S72) were included, without specifying the anatomical location. In the second analysis, only specific codes $(720,721,722)$ related to proximal femur fracture were included. The proportion of hospital deaths among the elderly was analyzed through the ratio of the number of elderly hospitalized for femoral fracture with the outcome of death by the number of elderly hospitalized by femur invoice. The files were transferred to the TAB tab program for Windows (TabWin) for data analysis. Descriptive statistics were used, and the absolute $(n)$ and relative (\%) frequencies of the number of hospitalizations for each variable were calculated.

As the data collected are in the public domain, made available electronically and without the identification of the research participants, this study did not require appreciation and approval by the Research Ethics Committee.

\section{RESULTS}

In Roraima, the proportion of elderly hospitalized between 2015 and 2019 was $11.4 \%$ (23.676). Of this total, the elderly hospitalized for femoral fracture represented $2.4 \%$ (578). The female gender was the most prevalent in hospitalizations for femoral fracture (56.4\%). Stratified by age group, 80 years and more represented $38.7 \%$ of hospitalizations, being more prevalent in women (69.6\%) (Table-1). When the hospitalizations were analyzed, specifying the anatomical location in fracture of the proximal femur, the women represented the majority $(60.6 \%)$. Stratified by age 
group, 80 years and over, it represented $44.7 \%$, with the majority of women $(70.3 \%)$ (Table-2). The occurrence of femoral fracture hospitalizations among the elderly with the outcome of death represented $5.2 \%$ (30), with mostly women aged 80 years or older $(66.7 \%)$

Table - 1 Hospitalizations for femoral fracture (without differentiating the anatomical location) by age group and gender. Roraima, Brazil, 2015 to 2019

\begin{tabular}{|c|c|c|c|c|c|c|}
\hline & \multicolumn{2}{|c|}{ Female } & \multicolumn{2}{|c|}{ Male } & \multicolumn{2}{|c|}{ Total } \\
\hline & $n$ & $\%$ & $\mathrm{n}$ & $\%$ & $\mathrm{n}$ & $\%$ \\
\hline $\begin{array}{l}60 \text { to } 79 \text { years } \\
\text { old }\end{array}$ & 90 & 45,9 & 106 & 54,0 & 196 & 100 \\
\hline $\begin{array}{l}70 \text { to } 79 \text { years } \\
\text { old }\end{array}$ & 80 & 50,6 & 78 & 49,3 & 158 & 100,0 \\
\hline $\begin{array}{l}80 \text { years and } \\
\text { older }\end{array}$ & 156 & 69,9 & 68 & 30,3 & 224 & 99,9 \\
\hline Total & 326 & 56,4 & 252 & 43,6 & 578 & 100,0 \\
\hline
\end{tabular}

Source: SIH/SUS, DATASUS.

Table - 2 Hospitalizations for femoral fracture (anatomical location of proximal femur) by age group and gender. Roraima, Brazil, 2015 to 2019.

\begin{tabular}{|c|c|c|c|c|c|c|}
\hline & \multicolumn{2}{|c|}{ Female } & \multicolumn{2}{|c|}{ Male } & \multicolumn{2}{|c|}{ Total } \\
\hline & $n$ & $\%$ & $\mathrm{n}$ & $\%$ & $\mathrm{n}$ & $\%$ \\
\hline 60 to 79 years old & 33 & 54,1 & 28 & 45,9 & 61 & 100,0 \\
\hline 70 to 79 years old & 33 & 51,5 & 31 & 48,4 & 64 & 100,0 \\
\hline $\begin{array}{l}80 \text { years and } \\
\text { older }\end{array}$ & 71 & 70,3 & 30 & 29,7 & 101 & 100,0 \\
\hline
\end{tabular}


Total

137

60,6

89

39,3

226

\section{0,0}

Source: SIH/SUS, DATASUS.

\section{DISCUSSION}

According to SIH/SUS records, from 2015 to 2019, Chapter XIX, Injuries, poisoning and other consequences of external causes, occupied the sixth position among the causes of hospitalizations among the elderly in Roraima, Brazil. From this chapter, femoral fracture represented the main cause of hospitalization. This type of fracture is one of the most common traumatic injuries in the elderly, and the advance of age and gender influence the increase in the occurrence in this population (WU et al., 2019; ARMOND et al., 2014; TSUDA, 2017).

The results found in this study are in line with other studies that indicate a higher frequency of femoral fracture hospitalizations among older women (PORTO et al., 2019; OLIVEIRA e BORBA, 2017). On femoral fracture hospitalizations with proximal anatomical localization, the profile found was similar, corroborating other studies (NETO et al., 2011; PAULA et al., 2015). For the most part, this type of fracture requires hospitalization for surgical treatment and presents a higher risk of morbidity and mortality and reduced quality of life (PAULA et al., 2015; ALMEIDA et al., 2017).

There is a relationship between the increase in cases of femoral fractures and advancing age, with the female gender being the most affected (BORTOLON et al., 2011). It is known that due to estrogen deficiency, menopausal women have a higher incidence of osteoporosis when compared to men. Thus, hip, spine and wrist fractures are more susceptible (CHEN et al., 2018). The decline in bone density, age, history of fracture, smoking, alcohol consumption and rheumatoid arthritis are the main risk factors associated with fractures in postmenopausal women (WU et al., 2019; TSUDA, 2017). Analyses showed that socioeconomic status and low educational level are also factors for the occurrence of the first fracture of hip structures, such as the proximal femur (CHEN et al., 2018). In addition, these data may portray the feminization of the phenomenon of population aging (ARMOND et

Available in: https://www.nucleodoconhecimento.com.br/health/femoral-fracture 
al., 2014). This is mainly due to the differences found in life expectancy between genders, and on the general average, women live longer than men (TRAVASSO et al., 2020).

Hospitalizations with the outcome of death due to femoral fracture were higher among older women, according to some epidemiological studies (BORTOLON et al., 2011; PORTO et al., 2019). An association was observed between older individuals and an increase in the femoral fracture mortality rate. However, some studies show a prevalence in mortality among older men (PETERLE et al., 2019; OLIVEIRA e BORBA, 2017). The higher proportion of women hospitalized for femoral fracture could justify the prevalence of hospital deaths in this group. However, a study conducted between 2008 and 2018 on hospital mortality among the Regions of Brazil showed higher mortality among hospitalized men. It was also observed that the costs resulting from this disease are high and present differences between the Brazilian Regions (PETERLE et al., 2019). Disagreements between the findings may be related to numerous variables arising from geography and climate, eating habits, health actions, risk factors, population constitution, and underreporting of cases (SOARES et al., 2014). Other risk factors involved may be the presence of more comorbidities, high surgical risk in individuals in this age group, presence of cognitive impairment and gender (EDELMUTH et al., 2018; NETO et al., 2011).

The aging phenomenon can increase the incidence of femoral fractures if preventive measures are not adopted (BEER and GILES, 2005). In addition to a higher risk of mortality, usually after the occurrence of the fracture, the elderly have some level of physical limitation, mental health impairment and reduced life expectancy (EDELMUTH et al., 2018; OLIVEIRA and BORBA, 2017; ALEXIOU et al., 2018).

The distribution of the elderly population is not homogeneous in Brazil, with regional differences. The Northern Region has the lowest concentration of the elderly, and $53.2 \%$ is represented by women (TRAVASSO et al., 2020). Despite this, population aging should be considered as one of the major challenges for the public health system, which is not prepared to meet this new demand. Strategies such as health education and fracture prevention should be adopted to reduce the negative impacts 
of this disease. In addition, the use of secondary data can help in the knowledge of the needs of the State and serve as support in strategies focused on health demands.

The main limitations of this study are associated with the use and quality of secondary data available in the SIH/SUS, such as underestimation of cases and the impossibility of knowing the causes that led to hospitalizations for femoral fractures. In addition, no population data were used, which requires more complete future studies, mainly due to the demographic characteristics of the State of Roraima.

\section{FINAL CONSIDERATIONS}

According to age and gender, it was observed that hospitalizations and hospital deaths due to femoral fracture were more prevalent in octogenarian women. Health strategies, such as the prevention of falls, should be directed to the elderly population, especially women, who are the most affected by this disease.In addition, joint actions aimed at improving well-being and quality of life should be adopted for a more active and healthy aging, always considering the reality and local demands.

\section{REFERENCES}

ALEXIOU, K. I. et al. Quality of life and psychological consequences in elderly patients after a hip fracture: a review. Clin Interv Aging. v. 24, n. 13, p. 143-150, 2018. doi: 10.2147/CIA.S150067

ALMEIDA, D. O. et al. Internações por fraturas ósseas pelo SUS em idosos do município de Salvador (BA): um estudo descritivo do ano de 2015. Rev. Ciênc. Méd. Biol. v. 16, n. 3, p. 288-295, 2017. doi: 10.9771/cmbio. v16i3.24384

ARMOND, J. E. et al. Caracterização de idosos internados por queda acidental na cidade de São Paulo, 2013. Rev. Bras. Geriatr. Gerontol. v. 8, n. 4, p. 200-203, 2014. 
BEER, C.; GILES, M. Hip fracture Challenges in prevention and management. Aus.Fam.Physician. v.4, n. 8, p. 673-676, 2005.

BORTOLON, P.C. et al. O perfil das internações do SUS para fratura osteoporótica de fêmur em idosos no Brasil: uma descrição do triênio 20062008. Cad. Saúde Pública. v. 27, n. 4, p. 733-742, 2011. doi: 10.1590/S0102$311 \times 2011000400012$

CARMO, W.M.; GOMES, L. S. M. Fraturas Trocantéricas. J Bone Joint Surg. v. 90, p. 700-7007, 2008.

CHEN, F. P. et al. Risk factors and quality of life for the occurrence of hip fracture in postmenopausal women. Biomed J. v. 41, n. 3, p. 202-208, 2018. doi: 10.1016/j.bj.2018.04.001

EDELMUTH, S. V. C. L. et al. Comorbidities, clinical intercurrences, and factors associated with mortality in elderly patients admitted for a hip fracture. Rev. bras. ortop. v. 53, n. 5, p. 543-551, 2018. doi10.1016/j.rboe.2018.07.014

MACEDO, G. G. et al. Fraturas do fêmur em idosos: um problema de saúde pública no Brasil. REAC. v. 6, n. 1112, p. 01-07, 2019. doi: 10.25248/reac. e1112.2019

NASCIMENTO, M.M. Queda em adultos idosos: considerações sobre a regulação do equilíbrio, estratégias posturais e exercício físico. Geriatr. Gerontol. Aging. v. 13, n. 2, p. 103-110, 2019.

NETO, J. S. H. et al. Características epidemiológicas e causas da fratura do terço proximal do fêmur em idosos. Rev Bras Ortop. v. 46, n. 6, p. 660-667, 2011. doi: 10.1590/S0102-36162011000600007

OLIVEIRA, C. C.; BORBA, V.Z.C. Osteoporosis in brazilian patients awaiting knee arthroplasty. Acta Ortop Bras. v. 25, n. 4, p. 155-158, 2017. doi: 10.1590/1413-785220172504168827 
PAULA, F. L. et al. Readmissão e óbito de idosos com alta após internação por fratura proximal de fêmur, ocorrida nos hospitais do Sistema Único de Saúde entre os anos de 2008 e 2010. Ver Bras Epidemiol. v. 18, n. 2, p. 439-453, 2015. doi: 10.1590/1980-5497201500020012

PETERLE, V.C. U. et al. Indicators of morbidity and mortality by femur fractures in older people: a decade-long study in brazilian hospitals. Acta Ortop Bras. v. 28, n. 3, p. 142-148, 2020. doi:10.1590/1413-7852202028032283

PORTO, A. O. et al. Características sociodemográficas e custo de hospitalizações por fratura de fêmur em idosos na Bahia. J Health NPEPS. v. 4, n. 2, p. 297-309, 2019. doi: 10.30681/2526101038233823

SANTOS, R. B. et al. Older adults' views on barriers and facilitators to participate in a multifactorial falls prevention program: Results from Prevquedas Brasil. Archives of Gerontology and Geriatrics. v. 92, p. 01-09, 2021. doi:10.1016/j.archger.2020.104287

SOARES, D. S. et al. Fraturas de fêmur em idosos no Brasil: análise espaçotemporal de 2008 a 2012. Cad. Saúde Pública. v. 30, n. 12, p. 2669-2678, 2014. doi: 10.1590/0102-311X00218113

TRAVASSO, G.F. et al. The elderly in Brazil: demographic transition, profile, and socioeconomic condition. Rev. bras. estud. popul. v.7, p. 01-27, 2020. doi: 10.20947/S0102-3098a0129

TSUDA, T. Epidemiology of fragility fractures and fall prevention in the elderly: a systematic review of the literature. Curr Orthop Pract. v. 28, n. 6, p. 580-585, 2017. doi: $10.1097 / B C O .0000000000000563$

WU, S.C. et al. The influence of ageing on the incidence and site of trauma femoral fractures: across-sectional analysis. BMC Musculoskelet Disord. v. 20, p. 413-419, 2019. Doi: 10.1186/s12891-019-2803-x 


\section{APPENDIX - FOOTNOTE}

[2] Sistema de Informações Hospitalares (SIH).

[3] Sistema Único de Saúde (SUS).

[4] Autorizações de Internações Hospitalares (AlH'S).

Submitted: August, 2021.

Approved: January, 2022. 